\title{
Contactless Hand Sanitizer for Healthy Village in Corona Pandemic Outbreaks
}

\author{
$1{ }^{\text {st }}$ Hari Maghfiroh \\ Dept. Electrical Engineering \\ Universitas Sebelas Maret \\ Surakarta, Indonesia \\ hari.maghfiroh@staff.uns.ac.id \\ $3^{\text {rd }}$ Henry Probo Santoso \\ Dept. Electrical Engineering \\ Universitas Sebelas Maret \\ Surakarta, Indonesia \\ henryprobo140198@gmail.com
}

\author{
$2^{\text {nd }}$ A. Sujono \\ Dept. Electrical Engineering \\ Universitas Sebelas Maret \\ Surakarta, Indonesia \\ agus.sjn.te16@gmail.com \\ $4^{\text {th }}$ Joko Slamet Saputro \\ Dept. Electrical Engineering \\ Universitas Sebelas Maret \\ Surakarta, Indonesia \\ jssaputro89@staff.uns.ac.id
}

\begin{abstract}
The corona pandemic has caused global problems, including Indonesia. One way to reduce the spread of the coronavirus is to wash your hands frequently with soap or hand sanitizer. Many types of hand sanitizers were developed to support efforts to prevent the spread of the corona. For this reason, this paper proposes two types of Contactless Hans Sanitizer (CHS) prototypes. Function tests and user satisfaction tests were carried out to determine the performance of the CHS. The test results show that type A CHS which only works fully electrically is more reliable than type $B$ which works with electrical and mechanical systems. Of the 10 respondents, $90 \%$ chose $C H S$ type $A$.
\end{abstract}

Keywords—corona, pandemic, hand sanitizer, contacless

\section{INTRODUCTION}

The corona pandemic cau sed by the Covid-19virus which emerged at the end of 2019 is still not over and is now troubling almost all countries in the world. According to data from John Hopkins University as of October 12, 2020, confirmed cases worldwide have reached 37,378,245 victims [1]. Indonesia its elf ranks 21 in the world in the number of corona cases with positive confirmed cases reaching 333,449 cases.

COVID-19 (Coronavirus disease-2019) which spreads through recent coronavirus 2 (SARS-CoV-2) characterize by acute respiratory disorder, pneumonia, dry cough, fever, and body paint at a high rate of mortality [2]. The virus, which first appeared in China, has a lower-Case Fatality Rate (CFR) than SARS, but the distribution is faster. So that the World Health Organization (WHO) established the status of Public Health Emergency of International Concern on January 30, 2020 [3].

Several ways have been done by countries in the world to prevent the spread of the coronavirus. Among them by providing special health facilities, carrying out rapid tests, carrying out regional quarantine, or lockdowns. In addition, as a preventive measure, several countries closed schools [4].

Infection caused by the coronavirus can spread through contact with sufferers, droplets, and airborne transmission. Until now, no treatment or vaccine has been found and the rate of infection with this virus is still increasing. To reduce the spread of the coronavirus, a preventive effort that can be done is to routinely was h your hands u sing soap or hand s anitizer and use a mask [5].

Based on the official website of the Indonesian government for developments in the condition of corona cases in Indonesia [6], positive confirmed cases of Covid-19 are still increasing every day, as can be seen in Figure 1. There have been many efforts made by the central and local governments to stop this corona pandemic. Both preventive and treatment for positive sufferers. The best effort to stop the spread of the corona is prevention because now there are many sufferers, and it is feared that the hospital will no longer be able to accommodate them.

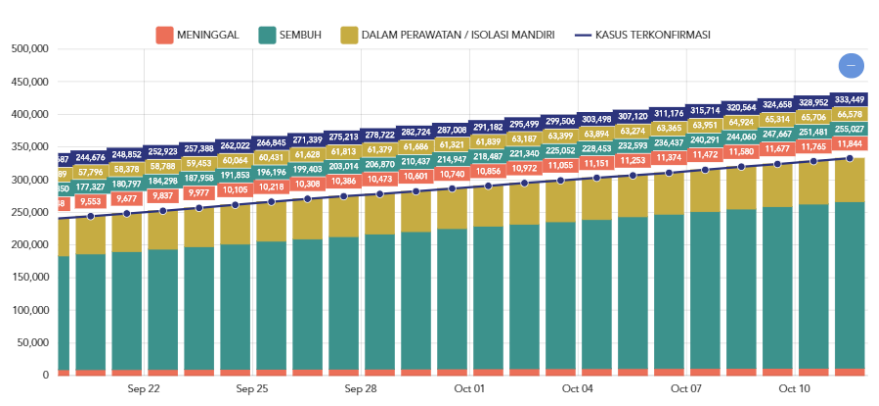

Fig. 1. Corona case in Indonesia Sept 22 to Oct 10 [6]

Many government campaigns have campaigned for preventive efforts to prevent corona, both in terms of regulations and suggestions for healthy living. One of the regulations is that the government has imposed a Local Lockdown or known as Pembatasan Sosial Berskala Besar (PSBB), as well as a ban on going home from another places. Mean while, in terms of prevention, the government by advising people to wear masks when leaving the house, wash their hands frequently with soap or hand sanitizer to prevent transmission of the coronavirus [7]. For this reason, in this study, a Contactless Hand Sanitizer (CHS) prototype is proposed. This prototype will later be placed in one of the public places in Prayunan Village to create a healthy village during the Corona pandemic outbreaks. 
This paperis organized as follows. Section II presents the material and method. In section III, the result and discussionare presented. Finally, the conclusion is in sectionIV.

\section{Material AND Method}

In this study, two prototypes of Contactless Hand Sanitizer (CHS) were proposed to help inhibit the spread of the coronavirus.

\section{A. CHS Type A}

Hand sanitizer is made using a submersible pump, $1 \mathrm{k} \Omega$ resistor, transis tor, 3.7 Volt battery, and infrared sensor. Figure 2 shows the CHS Type A circuit scheme. The hand sanitizer works automatically by bringing the hand closer to theinfrared sensor, then the liquid disinfectant will be pumped out by the submersible pump.

The hand sanitizer casing uses acrylic material and is designed using Corel Draw software, resulting in design as shown in Figure 3. The casing design is used for laser cutting of acrylic. The casing is designed to be able to store bottles filled with disinfectant liquid and protect electronic components from the outside environment. The bottle containing the dis infectant liquid can be refilled through the bottle cap on the top of the casing. Figure 4 shows the finished CHS Type A, later this CHS can be placed on a table or hung on the wall.

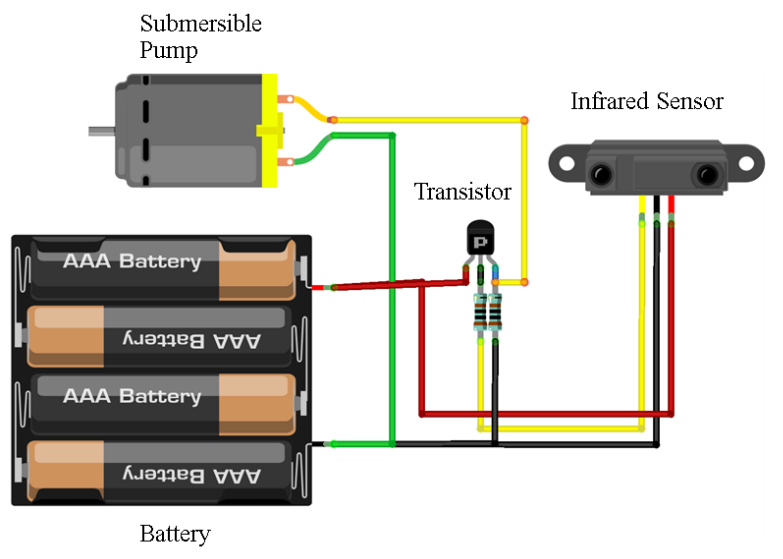

Fig. 2. Schematic of the type A hand sanitizer

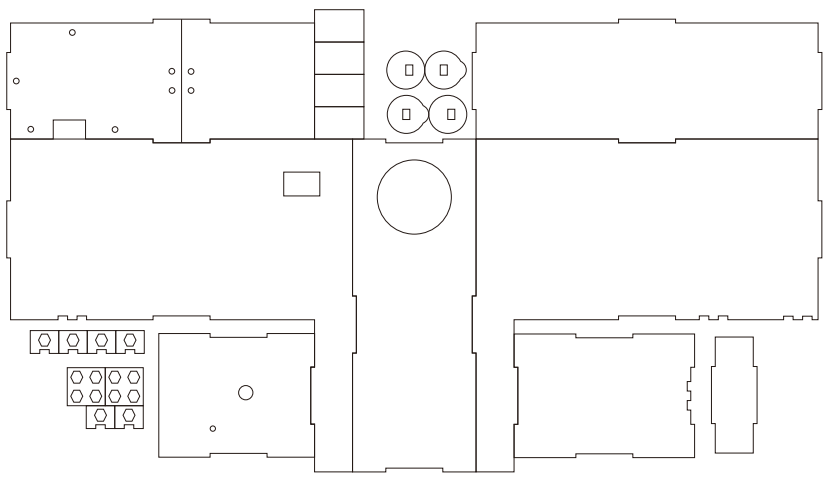

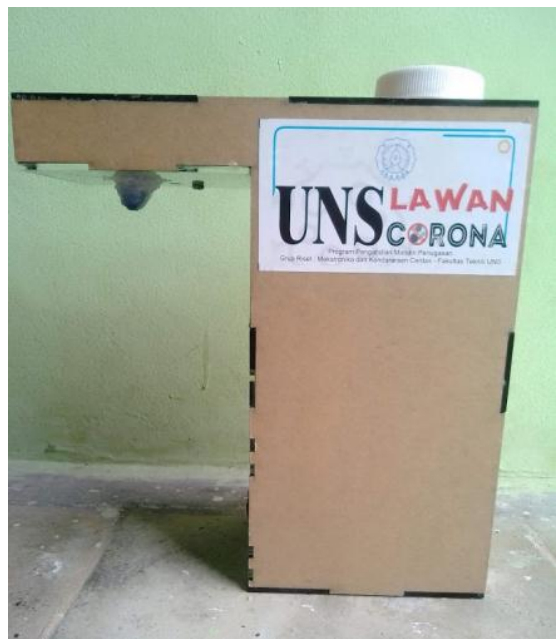

Fig. 4. Hand-sanitizer type A

\section{B. CHS Type B}

Hand sanitizer is made using a dc motor, $1 \mathrm{k} \Omega$ resistor, transis tor, 3.7-volt battery, and infrared sensor. Figure 5 shows the CHS Type B circuit. The components are the same as the CHS Type A, the differences is the DC motor on the CHS Type $\mathrm{A}$ is a mini submersible pump, while in this type, the DC motor is a wheel rotating motor. While the wheels function mechanically to press the hand-sanitizer sprayer.

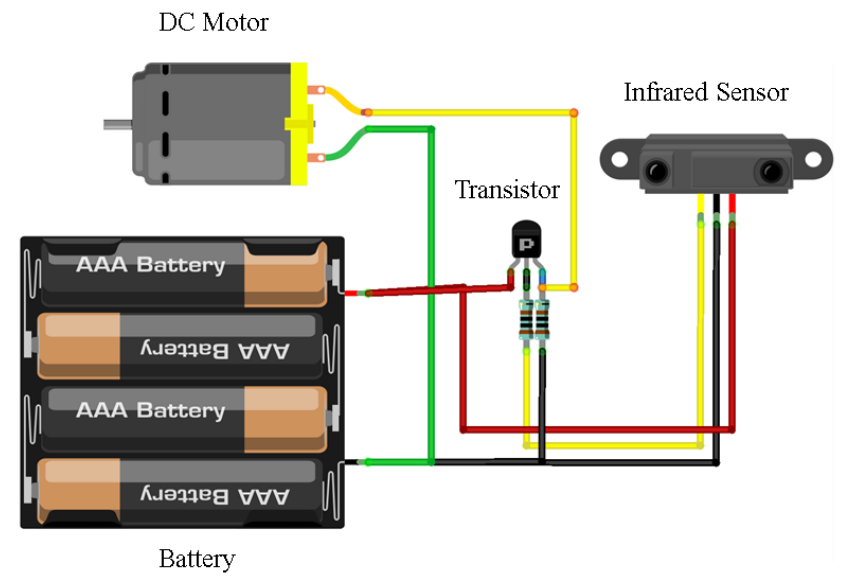

Fig. 5. Schematic of the type B hand sanitizer

The hand sanitizer casing uses acrylic material and is designed using Corel Draw software, resulting in design as shown in Figure 6. The casing design is used for laser cutting of acrylic. The casing is designed to store spray bottles filled with dis infectant liquid and protect electronic components from the outside environment. The bottle containing the disinfectant can be refilled by removing the spray bottle attached to the front. This type of design is devoted to wall-hanging installation only. The final prototype of CHS type B is shown in Figure 7.

Fig. 3. Type A hand-sanitizer casing design 


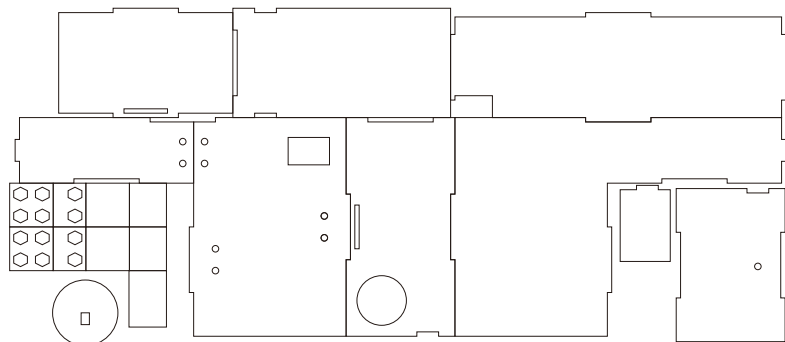

Fig. 6. Type B hand-sanitizer casing design

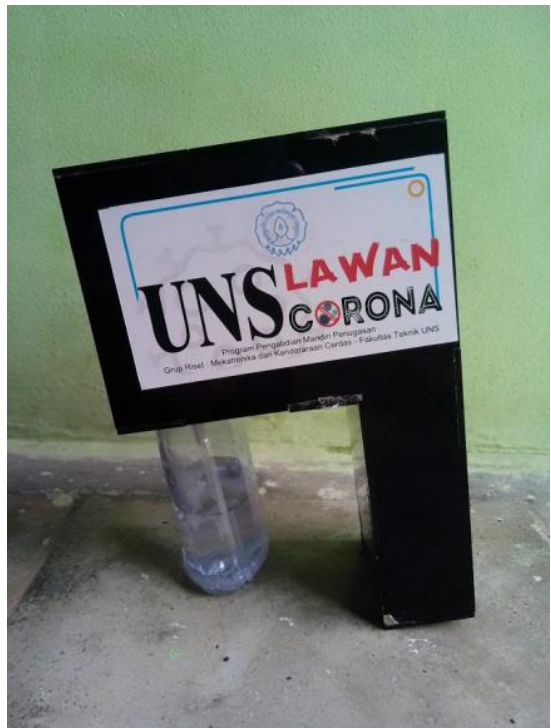

Fig. 7. Hand-sanitizer type B

\section{Result And Discustion}

To find out the performance of the two types of CHS that have been made, function testing and user satisfaction are tested.

\section{A. Function Test}

The function test was carried out to determine whether the CHS prototype that was made could work properly. The test results showed that the two types of CHS were made to work well. The hand distance to the CHS can be adjusted by adjusting the sensitivity of the sensor by turning the trimpot on the sensor. However, the problemfaced is that the sensitivity of the sensor depends on the light around the CHS usage s pace. If the CHS is set in an open area with light, then when brought to a closed room the sensor reading dis tance will decrease. Conversely, if the sensor is set in a closed room, then when taken outside the room the sensor will activate itself because there is too much light. The solution to this problemis to place the CHS in a fixed place.

When the CHS is placed in a fixed place, it turns out that after being tested, the difference in the intensity of day and night light also affects the infrared sensor. For this reason, the use of infrared sensors is recommended to be replaced with other sens ors such as motion sensors or temperature sensors to detect human body temperature.
Because both types of CHS have the same circuit scheme, the sens or constraints are the same. Mean while, because the mechanical system is different, they also have different performance. CHS type A works electrically by utilizing a mini dc-submersible pump so that there are no mechanical obstacles. Mean while, CHS type B, which utilizes the motor's mechanical motion to press the spray, found problems, sometimes the spray does not come out smoothly because the spray pres sing mechanism by the DC motor is not smooth. However, the systemcan still work.

\section{B. User Satisfaction Test}

The user satisfaction test aims to determine user impressions and suggestions of the two CHS designs that have been made. About 10 users were asked to try the CHS that had been made, then a short interview was conducted about the preferred type and the suggestions on the two designs that had been made.

Table 1 shows the test results of 10 users which showed $90 \%$ of users liked CHS type A and only $10 \%$ chose CHS type B. Since hand laying on type A is easier and better. This is because in type $A$ the hand is below while in type $B$ the hand is in front of the tool. The illustration on how to use both CHS is shown in Figure 8.

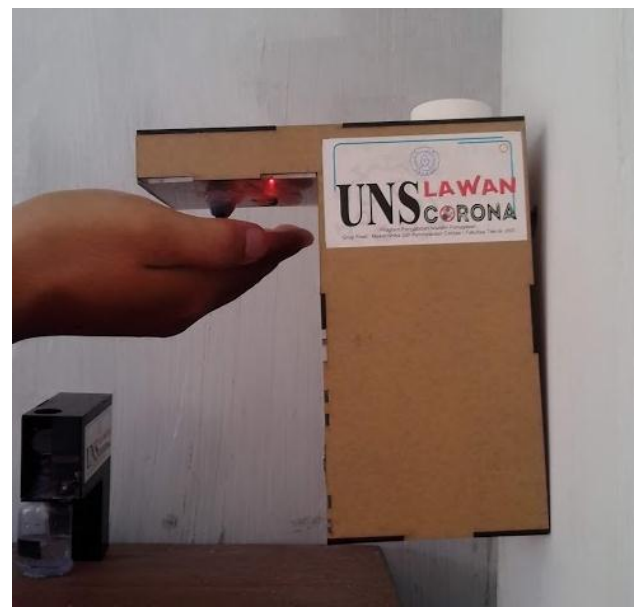

(a) Use of CHS type A

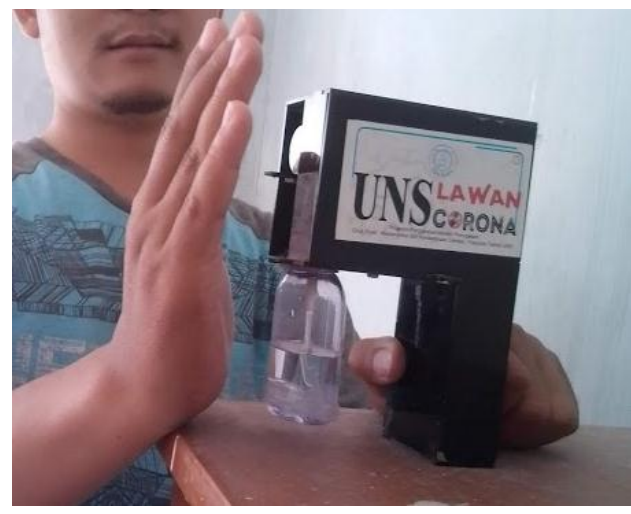

(b) Use of CHS type B

Fig. 8. How to use both CHS 
TABLE I. USER SATISFACTION TeSt RESUlt

\begin{tabular}{ccc}
\hline Users & Type A & Type B \\
\hline \hline 1 & $\sqrt{ }$ & \\
2 & $\sqrt{ }$ & \\
3 & $\sqrt{ }$ & \\
4 & $\sqrt{ }$ & $\sqrt{ }$ \\
5 & & \\
6 & $\sqrt{ }$ & \\
7 & $\sqrt{ }$ & \\
8 & $\sqrt{ }$ & \\
9 & $\sqrt{ }$ & \\
10 & $\sqrt{ }$ & \\
& & \\
\hline
\end{tabular}

\section{CONCLUSION}

Two prototypes of the CHS have been made. Function tests and user satisfaction tests have been carried out. The function test results show that both types of CHS can work, but the CHS type A is more reliable because the system is fully electric. Mean while, CHS type B, which works by a combination of electric and mechanical, is often constrained by its mechanical sys tem. Us er satisfaction test results also show the same thing, CHS type $\mathrm{A}$ is in demand by $90 \%$ of 10 users. This is because the position of the hand using type $\mathrm{A}$ is easier. In addition, CHS type A also rarely chokes because the systemis fully electric.

\section{ACKNOWLEDGMENT}

This research is funded by Hibah Pengabdian Mandiri Penugasan Covid, PNBP UNS 2020. Contract No. 127/UN27.21/HK/2020.

\section{REFERENCES}

[1] https://coronavirus.jhu.edu/ (accessed: October 12, 2020, at 7.30 Indonesian time)

[2] Mahmood, A., Eqan, M., Pervez, S., Alghamdi, H.A., Tabinda, A. B., Yasar, A., Brindhadevi, K., Pugazhendhi, A., COVID-19 and frequent use of hand sanitizers; human health and environmental hazards by exposure pathway, Science of the Total Environment, 2020. Doi: 10.1016/j.scitotenv.2020.140561.

[3] Suni, N.S.P., Kesiapsiagaan Indonesia Menghadapi Potensi Penyebaran Corona Virus Desease, Info Singkat, Kajian Singkat Terhadap Isu Aktual dan Strategis, Vol. 12, No.3, Badan Keahlian DPR RI.

[4] Agustino, L., Analysis of Covid-19 outbreak handling policy: the experience of Indonesia, Jurnal Borneo Administrator, Vol. 16, No.2, 2020. Doi: 10.24258/jba.v16i12.685.

[5] Pradhan, D., Biswasroy, P., Naik, P.K., Ghosh, G., Rath, G., A Review of Current Interventions for COVID-19 Prevention, Archives of Medical Research, 2020. Doi: 10.1016/j.arcmed.2020.04.020

[6] https://covid19.go.id// (accessed: October 12, 2020, at 08.00 Indonesian time)

[7] https://promkes.kemkes.go.id/menuju-adaptasi-kebiasaanbaru (accessed: October 12, 2020, at 08.00 Indonesian time) 